\title{
Selected aspects of the technological processes of the aircraft engine washing
}

\author{
Anna Rudawska ${ }^{1}$, Przemystaw Wrona ${ }^{1}$, Izabela Miturska $^{1, *}$, and Miroslav Müller ${ }^{2}$ \\ ${ }^{1}$ Lublin University of Technology, Faculty of Mechanical Engineering, Department of Production Engineering, Nadbystrzycka 36, \\ 20-618 Lublin, Poland \\ ${ }^{2}$ Czech University of Life Sciences Prague, Faculty of Engineering, Agricultural Engineering, Kamýcká 129, 16521 Prague, Czech \\ Republic
}

\begin{abstract}
In production, treatment or operation of selected components it is not possible to avoid dirtiness. Given the fact that impurities significantly affect the quality, functionality and service life of a part, the surface preparation of such an element is a key aspect in the regeneration process. The choice of contaminant removal method will depend on the type of impurity. This operation is often treated as a separate technological process, during which the type and properties of the removed dirt are determined, along with assessing the degree of purity required to ensure the correctness of subsequent operation or operations. Rising expectations regarding specific effects of purification have led to massive improvement of traditional methods, and development of new processes that require the use of complex technologies. The present research was to prepare the technological process of washing selected parts of the aircraft turbine engine. The preliminary assumption was to use the LUA-1000 automatic washing processing line, which selecting and modifying particular parameters of the process in order to comply with the technological assumptions. The elaborated process includes the following stages: preparing the selected parts for washing, washing the engine parts and the quality control of washing. The primary objective of the study was to achieve the most beneficial parameters possible and, at the same time, to minimise the costs of the machine's work, as well as to preserve high quality and to comply with environmental standards.
\end{abstract}

\section{Introduction}

It is not possible to prevent the parts from becoming contaminated during the process of production and treatment. Due to the fact that the impurities affect a given part's quality, functionality and life, it is of high importance to prepare its surface during such processes as regeneration, bonding or protective and decorative coating [1-8]. Cleaning machines and devices is aimed at removing various types of impurities affecting the quality of the assembled products, both inside and outside. Due to some differences, it may be divided into four groups:

- in order to gain good-quality inseparable connections and joints, e.g. soldered connections and glue joints, welded joints made with the use of various methods, as well as in case of electric and frictional welding, it is necessary to clean the surface from the external impurities and the oxide film:

- high-precision components of control systems, such as mechanical, hydraulic or pneumatic, require proper cleaning of chemical substances and particles that adhere to their surface,

- less important system parts require cleaning the residues of the foreign matter on the surface because of the production process and that could lead to the corrosion process or accelerate the part's wear (the residues of surfactants, detergent solutions or cooling and lubricating liquids),

- the regeneration and renovation of certain parts may require the removal of damaged layers and coatings, e.g. decorative, protective and wear-resistant ones, as well as of the exploitation deposit in order to restore the original state $[9,10]$.

The selection of the method of removal depends on the properties of impurities, and the removal is often recognised as a separate technological process. During this process it is necessary to determine the kind and properties of the impurities that are to be removed, as well as the degree of purity that is required for the next operations or further exploitation to be correct. The method and process of cleaning, as well as the composition of detergent solutions and the method of quality control have to be determined. A proper choice and setting-up of various devices also plays a vital role in the process [11-17].

The following criteria have been shown to be helpful in the rational choice of the surface cleaning method:

- safety criterion,

- technical criterion,

- economical criterion,

*Corresponding author: i.miturska@pollub.pl 
- maintainability criterion,

- ecological criterion [18, 19].

Massive improvement of traditional methods, as well as development of the new ones that require complex technologies has resulted from the need for specific effects of cleaning [20-24]. As the renovation of aircraft engines requires precision and accuracy, all the parts have to be cleaned properly. In order to meet these requirements, the newest cleaning methods are used. Their most vital advantages include optimal processes that generate low costs, as well as high quality of the cleaned parts. Moreover, verification as well as further stages of engine renovation may be carried out immediately after cleaning. Nowadays, automatic washing process lines are used in aircraft engine renovation process. Their work is always based on the technological process elaborated before. The process is adjusted to the purification method used by the machine or device, degree and kind of the impurities, type of the cleaned parts and the material they are made of.

The aim of this article was to elaborate a technological process of washing selected parts of the aircraft turbine engine with the use of the automatic washing process line. The process line in question belongs to the machine park of an aviation company operating in the Lubelskie region.

\section{Research Assumptions}

The article assumed the elaboration of the technological process of washing selected parts of the aircraft turbine engine in order to increase their durability and reliability. To this end, an automatic washing process line, which is specifically suitable in engine renovation process applications, was used. As the line works constantly, it is necessary to modify the process parameters in order to comply with the technological assumptions. Hence, substantial work has been undertaken in order to elaborate a detailed technological process.

\subsection{Specification of the Used Parts}

An aircraft turbine engine consists of the following basic parts: induction system, compressor, combustion chamber, exhaust system and co-working parts: gearbox, engine and airframe supplying systems (oil system, fuel system, air system). Due to the function of particular components, loads and working temperature, appropriate materials have to be used. The "cold" engine parts (induction system, gearbox and supplying systems) are made of materials of high specific strength (strength to density ratio), corrosion-resistance and mechanical properties' uniformity and stability. As far as the "hot" engine parts are concerned (combustion chamber, compressor and exhaust system), they have to comply with not only the aforementioned characteristic, but also have to be heat-resistant and show creep resistance in high-temperatures. Basic types of materials used for the modern aircraft turbine engines designs are: titanium alloys, steels and nickel-based superalloys. Light aluminium or magnesium alloys are used only in certain parts, e.g. fuselages, the first stages of compressors, gears or oil and fuel pumps. In addition, the composite materials are more and more often used in modern constructions.

An aircraft turbine engine scheme, as well as the alloys used for production of specific subassemblies are shown in Figure 1.

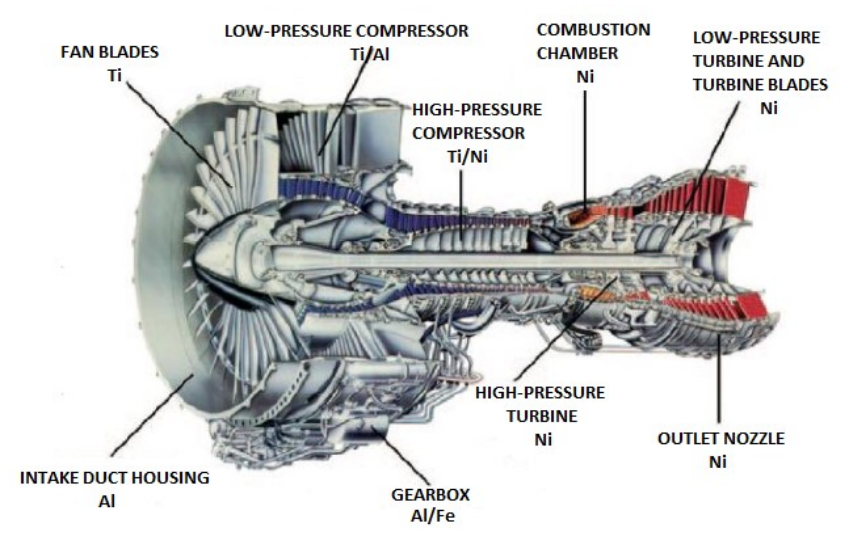

Fig. 1. An aircraft turbine engine's scheme and the alloys used for production of specific subassemblies [25].

The aforementioned factors contribute to the formation of various impurities. Depending on the material type and the degree of contamination, the engine parts designated for washing are divided into: steel alloys (slightly soiled steel, soiled steel, excessively soiled steel), titanium alloys (slightly soiled titanium, soiled titanium, and excessively soiled titanium), aluminium alloys and others (e.g. magnesium and copper alloys). Proper cleaning of aircraft engine parts during the renovation process leaves room for appropriate verification of the degree of the engine wear. It is of high importance to be careful so as not to damage the verified surfaces and not to break the original material of the washed part. Hence, it is necessary to qualify the soiled part properly so as not to cause its etching as a result of excessive washing. During the verification or regeneration processes, the renovated part may be soiled (e.g. with liquid or developer after having performed the liquid-penetration method, or with treatment liquid). In such cases, so called intermediate washing is being performed.

\subsection{Cleaning Process}

The cleaning process is fully automated, and employs two washing methods:

- ultrasonic cleaning-immersion,

- immersion.

Depending on the material of a given part is, as well as on the degree of contamination, four exemplary detergents by Chemtall company were used: Ardrox 6333A, Ardox A/185L, Ardox A/188, Ardox A/1873. The characteristics of all the detergents are shown in Table 1. 
Table 1. Characteristics of detergents used for washing [own study based on 26].

\begin{tabular}{|c|c|c|c|c|}
\hline & \multicolumn{4}{|c|}{ Detergent } \\
\hline & $\begin{array}{c}\text { Ardrox } \\
6333 \mathrm{~A}\end{array}$ & $\begin{array}{c}\text { Ardox } \\
\mathrm{A} / 185 \mathrm{~L}\end{array}$ & $\begin{array}{l}\text { Ardox } \\
\text { A/188 }\end{array}$ & $\begin{array}{c}\text { Ardox } \\
\text { A/1873 }\end{array}$ \\
\hline Reaction & alkaline & $\begin{array}{l}\text { highly } \\
\text { alkaline }\end{array}$ & $\begin{array}{l}\text { highly } \\
\text { alkaline }\end{array}$ & subacid \\
\hline $\begin{array}{c}\text { Washing } \\
\text { Temperature }\end{array}$ & $60-82{ }^{\circ} \mathrm{C}$ & $82-88^{\circ} \mathrm{C}$ & $82-93^{\circ} \mathrm{C}$ & $80-85^{\circ} \mathrm{C}$ \\
\hline $\begin{array}{l}\text { Concentration } \\
\text { (volume) }\end{array}$ & $5-30 \%$ & $15-60 \%$ & $10-25 \%$ & $20-25 \%$ \\
\hline $\begin{array}{l}\text { Washing } \\
\text { Method }\end{array}$ & $\begin{array}{l}\text { ultrasonic } \\
\text { cleaning- } \\
\text { immersion }\end{array}$ & immersion & immersion & immersion \\
\hline $\begin{array}{l}\text { Type of the } \\
\text { Removed } \\
\text { Impurities }\end{array}$ & $\begin{array}{c}\text { fats, oil } \\
\text { films, } \\
\text { lubricating } \\
\text { grease, } \\
\text { carbon } \\
\text { deposit } \\
\text { exhaust gases } \\
\text { residues } \\
\end{array}$ & $\begin{array}{c}\text { fats, oil } \\
\text { films, } \\
\text { lubricating } \\
\text { grease, } \\
\text { carbon } \\
\text { deposit } \\
\text { enamel, } \\
\text { corrosion } \\
\end{array}$ & $\begin{array}{l}\text { carbon } \\
\text { deposit, } \\
\text { scale } \\
\text { formed in } \\
\text { high } \\
\text { temp. }\end{array}$ & $\begin{array}{l}\text { carbon } \\
\text { deposit, } \\
\text { scale } \\
\text { formed in } \\
\text { high } \\
\text { temperature }\end{array}$ \\
\hline $\begin{array}{c}\text { Type of } \\
\text { Washed Parts }\end{array}$ & $\begin{array}{c}\text { steel, } \\
\text { titanium, } \\
\text { aluminium, } \\
\text { zinc, copper } \\
\text { and } \\
\text { magnesium } \\
\text { alloys } \\
\end{array}$ & $\begin{array}{l}\text { steel and } \\
\text { titanium } \\
\text { alloys }\end{array}$ & $\begin{array}{l}\text { heat- } \\
\text { resisting } \\
\text { and high- } \\
\text { temp. } \\
\text { creep } \\
\text { resisting } \\
\text { steel alloys }\end{array}$ & $\begin{array}{c}\text { heat- } \\
\text { resisting and } \\
\text { high- } \\
\text { temperature } \\
\text { creep } \\
\text { resisting } \\
\text { steel alloys } \\
\end{array}$ \\
\hline
\end{tabular}

After washing the parts with the use of the aforementioned detergents, they have to be rinsed in water in order to remove the chemical residues. Afterwards, prior to drying, the final rinse in demineralised water has to be performed: it will help to avoid streaks and seepage formation on the surface. In addition, the washed surface has the unloaded electrostatic charge, to which it owes higher soilresistance.

\subsection{Machines and Devices Used in the Washing Process}

The cleaning process used in the research was fully automated and performed with the use of the LUA-1000 automatic washing process line produced by the ULTRON company. The technical specifications of the machine are shown in Table 2.

Table 2. Technical specification of the washer [own study].

\begin{tabular}{|c|c|c|}
\hline \multirow{2}{*}{ Characteristic } & \multicolumn{2}{|c|}{ Dimension } \\
\hline \multirow{3}{*}{ Washer's external dimensions } & Length & $14200 \mathrm{~mm}$ \\
\cline { 2 - 3 } & Width & $2150 \mathrm{~mm}$ \\
\cline { 2 - 3 } & Height & $3150 \mathrm{~mm}$ \\
\hline \multirow{2}{*}{ Basket's internal dimensions } & Length & $600 \mathrm{~mm}$ \\
\cline { 2 - 3 } & Width & $600 \mathrm{~mm}$ \\
\cline { 2 - 3 } & Height & $600 \mathrm{~mm}$ \\
\hline Basket's maximum load & \multicolumn{2}{|c|}{$80 \mathrm{~kg}$} \\
\hline Manipulator's maximum load & \multicolumn{2}{|c|}{$130 \mathrm{~kg}$} \\
\hline Number of tanks (W) & \multicolumn{2}{|c|}{$11+$ dryer } \\
\hline Tanks' usable dimensions & Length & $850 \mathrm{~mm}$ \\
\cline { 2 - 3 }
\end{tabular}

\begin{tabular}{|c|c|c|}
\hline \multirow[t]{2}{*}{ W1-W11 } & Width & $800 \mathrm{~mm}$ \\
\hline & Depth & $700 \mathrm{~mm}$ \\
\hline $\begin{array}{l}\text { Usable capacity of the particular } \\
\text { tanks W1-W11 }\end{array}$ & \multicolumn{2}{|c|}{$\approx 6001$} \\
\hline Used materials & \multicolumn{2}{|c|}{$\begin{array}{c}\text { Steel } 1.4301 \\
\text { Steel } 1.4401(\operatorname{tank} W 9)\end{array}$} \\
\hline $\begin{array}{l}\text { Power of heaters in the particular } \\
\text { tanks }\end{array}$ & \multicolumn{2}{|c|}{$9 \times 18 \mathrm{~kW}$} \\
\hline Power of drying heaters & \multicolumn{2}{|c|}{$18 \mathrm{~kW}$} \\
\hline Power of ultrasounds & \multicolumn{2}{|c|}{$2 \times 3 \mathrm{~kW}$} \\
\hline Total installed power & \multicolumn{2}{|c|}{$189 \mathrm{~kW}$} \\
\hline Power supply & \multicolumn{2}{|c|}{$3 \times 400 \mathrm{~V} / 50 \mathrm{~Hz}+\mathrm{N}+\mathrm{PE}$} \\
\hline Water supply & \multicolumn{2}{|c|}{$1.5-8$ bar } \\
\hline Compressed-air supply & \multicolumn{2}{|c|}{$5-10$ bar } \\
\hline $\begin{array}{l}\text { Washing and rinsing temperature } \\
\text { range }\end{array}$ & \multicolumn{2}{|c|}{$10-90^{\circ} \mathrm{C}$} \\
\hline Drying temperature range & \multicolumn{2}{|c|}{$20-110^{\circ} \mathrm{C}$} \\
\hline
\end{tabular}

The washer is fully automated and controlled by a PLC. The elements that are to be washed are transported in the placed on a trolley to the load area. W1-W11 tanks have to be filled with water, detergents and heated to the appropriate temperature. Depending on the types of washed parts, washing method and stages, different types of washing agents are used in each tank. The washing process with the use of an automated process line includes: preparation of the selected parts for washing, washing the engine parts and the quality control of the performed washing. An exemplary scheme of the washing process with the use of an automatic process line includes the following stages: inductive sensors in the load area detect the basket, after choosing the particular program and approving it by the operator, the basket is lifted by the manipulator and transported to the first tank in the process. After washing is done, the manipulator transports the basket to the next tank where the technological process is continued. Two tanks for washing are equipped with ultrasounds (W2 and W6). Tanks for preliminary and main washing (W1, W2, W6 and W8) are equipped with the off-line filtration system and the surface rinsing system. This system helps to remove grease from the liquid surface by enabling to take out the basket without letting the dissolved grease deposit on the washed part's surface. Every tank, apart from W2 and W6 (ultrasonic cleaning) is equipped with the liquid mixing system. In the case of the process tanks, the mixing pump starts to work 1 minute before the basket is put into the tank and continues to work until the basket is taken out of the tank. Thanks to this the bath is preliminarily mixed which improves washing efficiency. When it comes to the rinsing tanks, the mixing starts when the basket is lowered to the tank with water and continues until the basket is taken out of it. The whole process is fluent, and all the parts are transported from one tank to another subsequently. The final rinsing is performed in the tank with demineralised water, which is also equipped with the off-line filtration system, as well as the demineralisator that works in a closed system. Before the process is finished, the basked is transported to the dryer (W12), where the 
washed elements are dried. Then, the manipulator transports the basket to the unload area and puts it on the trolley, which constitutes the final operation, following which the whole process is finished.

Due to certain technological reasons, the machine is equipped with two manipulators moving along the guides in two directions: along the washer and upwardsdownwards. Each manipulator is driven by two engines with the use of motoreducers and a gear wheel a toothed bar (lengthwise direction) and a screw drive (vertical direction). The maximum carrying power of the manipulators is determined in the technical specification. The baskets are made of wire net with large mesh, which enables removing the impurities from the washed parts. Water for tanks is taken from the water pipe network with the use of electro valves that control the filling of every tank separately. The water or detergent level is controlled by the level induction sensors installed at every tank, and is displayed on the PLC. The tanks are emptied manually with the use of ball valves. The tanks may be emptied separately or simultaneously, if necessary. The liquid may be removed by gravity or with the use of a pump. Every tank is equipped with a slideable cover that is closed when working. It prevents heat loss and liquid evaporation, as well as provides acoustic isolation. The covers are moved by pneumatic actuators.

\subsection{Technological Assumptions}

While working on the washing process, one has to aim for the most efficient parameters, the lowest costs connected with the machine's work (necessary utilities and time) and the highest quality possible. The main assumptions of the optimisation include:

- maximum use of the basket load space - taking into consideration the weight $(80 \mathrm{~kg})$ and volume $(600 \mathrm{x} 600$ $\mathrm{x} 600 \mathrm{~mm}$ ) limitations, the washing process should be performed with the lowest load possible. On the other hand, the washed elements should be arranged in such way as to enable the washing liquid and ultrasounds reach the whole washed surface. To this end, special baskets with barriers (Fig. 2) are used - they make the washing process efficient and safe.

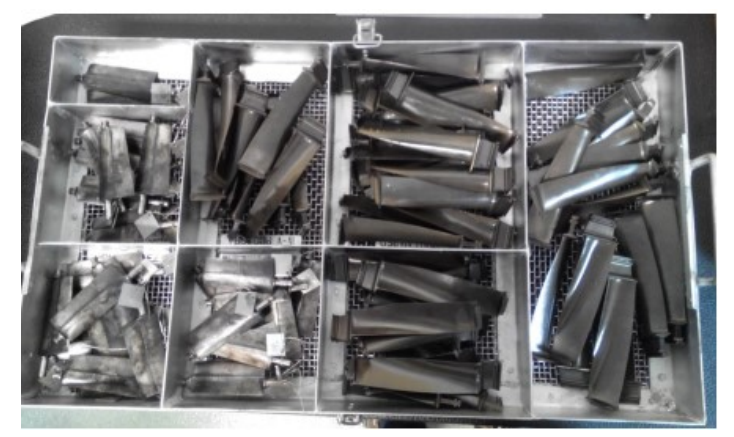

Fig. 2. The arrangement of the fan blades of the aircraft turbine engine in the basket before the washing process.

- temperature and bath time reduction - heating water and maintaining desired temperature in every tank with an average capacity of 6001 requires considerable resources of electric power. Temperature reduction by every single degree enables saving the electric power. However, bath time reduction leads to the increase in the number of charges during one change, which enables faster wear of the equipment.

- increase in the concentration - it reduces the bath time and temperature. However, it has to be underlined that too high a concentration may cause etching of the washed parts, and exceeding the specified value may not improve the washing quality.

- reduction of the bath change frequency - the washing liquid is being soiled during the washing process, which reduces its efficacy and affects the washing quality. As a result, the bath temperature has to be risen, the time of bath is prolonged, and the baths have to be changed more often. The cost of bath change (sewage treatment, removal of the current chemicals and replacing them with new ones) may amount even up to a few thousand zlotys. A limited number of bath changes may be reached through rinsing in water every time after the basket is taken out of the process tank. It prevents the chemicals from mixing thanks to the use of the off-line filtration system in every tank containing detergents.

\section{Elaborated Technological Process}

The technological process of washing selected parts of the aircraft turbine engine is one of the key stages in its renovation process. The use of the LUA-1000 automatic washing process line ensures the highest economic and environmental standards. The elaborated technological process presents the flow of washing of the most soiled steel elements of the aircraft engine, which is currently being renovated by the aviation company. It is the longest process during which the elements are washed in four tanks, rinsed in five tanks and then dried. The engine parts washed in the process include, inter alia, the parts of turbine - discs, discs protectors, blade-ring rotor blades and nozzles. The washing process consists of three stages: preparation of the selected parts for washing, washing the engine parts and the quality control of the performed washing. The flowchart washing process is shown in Figure 3. 


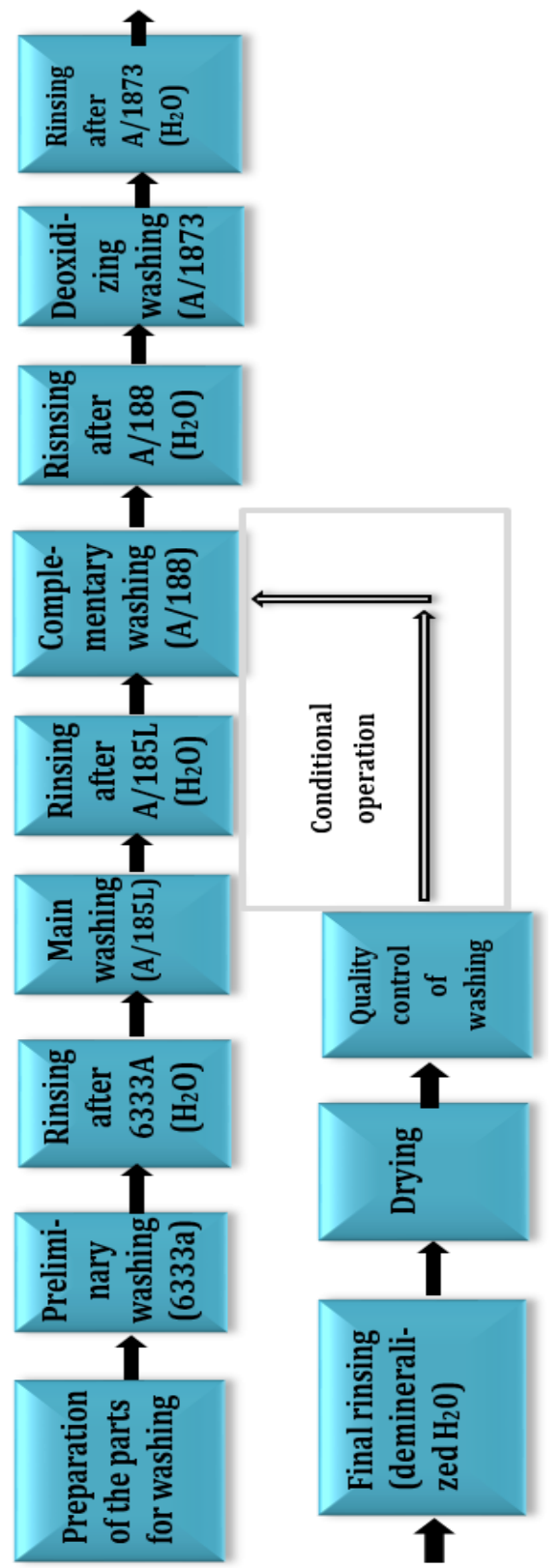

Fig. 3. Flowchart of excessively contaminated parts' washing.

The process also assumes performing a conditional operation, as its repeatability in terms of the detergents' effectiveness is high but the degree of contamination of renovated engines may differ depending on:

- the amount of overhaul life between renovations (the engine could still have some margin of hours, yet was sent for renovation due to the number of cycles),

- the environment where the aircraft was used,

- the technical culture standards according to which the engine was used,

- the reasons for being sent for renovation (e.g. a foreign body sucked into the engine).

The elaborated process was optimised according to the aforementioned technical assumptions. As a result, the highest quality and the lowest costs possible were achieved.
Table 3 shows the parameters for subsequent stages of the technological process.

Table 3. The parameters for particular stages of the technological process of the selected parts of the aircraft engine washing.

\begin{tabular}{|c|c|c|}
\hline Stage & \multicolumn{2}{|c|}{$\begin{array}{c}\text { Content of the } \\
\text { operation/Process parameters }\end{array}$} \\
\hline $\begin{array}{l}\text { Preparation of the } \\
\text { selected parts for } \\
\text { washing }\end{array}$ & \multicolumn{2}{|c|}{$\begin{array}{l}\text { 1. Put the basket into the trolley. } \\
\text { 2. Arrange the parts in the basket } \\
\text { so as to minimise the amount of } \\
\text { liquid on the surface after the } \\
\text { washing process. } \\
\text { 3. Attach the parts to the basket } \\
\text { using a stainless cord so as to } \\
\text { prevent them from moving } \\
\text { during washing. } \\
\text { 4. Place the trolley with the } \\
\text { basket on the loading station. } \\
5 \text {. Select: "excessively soiled } \\
\text { steel" process. } \\
6 . \text { Turn the process on. }\end{array}$} \\
\hline \multirow{7}{*}{$\begin{array}{l}\text { Preliminary } \\
\text { washing. }\end{array}$} & washing method & ultrasounds \\
\hline & washing liquid & $\begin{array}{l}\text { Ardrox } \\
6333 \mathrm{~A}\end{array}$ \\
\hline & concentration & $15 \%$ \\
\hline & Temperature $\mathrm{T}$ & $65^{\circ} \mathrm{C}$ \\
\hline & bath time $t_{k}$ & 20 minutes \\
\hline & draining time $t_{o}$ & 1 minute \\
\hline & $\begin{array}{l}\text { manipulator } \\
\text { moving } \\
\text { time } \mathrm{t}_{\mathrm{m}}\end{array}$ & 1 minute \\
\hline \multirow{7}{*}{$\begin{array}{l}\text { Rinsing after the } \\
\text { preliminary } \\
\text { washing }\end{array}$} & washing method & immersion \\
\hline & washing liquid & $\mathrm{H}_{2} \mathrm{O}$ \\
\hline & concentration & - \\
\hline & Temperature $\mathrm{T}$ & $70^{\circ} \mathrm{C}$ \\
\hline & bath time $t_{k}$ & 1 second \\
\hline & draining time $t_{o}$ & 1 minute \\
\hline & $\begin{array}{l}\text { manipulator } \\
\text { moving } \\
\text { time } \mathrm{t}_{\mathrm{m}}\end{array}$ & 1 minute \\
\hline \multirow{7}{*}{ Main washing } & washing method & immersion \\
\hline & washing liquid & $\begin{array}{r}\text { Ardox } \\
\text { A/185L } \\
\end{array}$ \\
\hline & concentration & $50 \%$ \\
\hline & Temperature $\mathrm{T}$ & $90^{\circ} \mathrm{C}$ \\
\hline & bath time $t_{k}$ & 25 minutes \\
\hline & draining time $t_{o}$ & 1 minute \\
\hline & $\begin{array}{l}\text { manipulator } \\
\text { moving } \\
\text { time } t_{\mathrm{m}} \\
\end{array}$ & 1 minute \\
\hline \multirow{7}{*}{$\begin{array}{l}\text { Rinsing after the } \\
\text { main washing }\end{array}$} & washing method & immersion \\
\hline & washing liquid & $\mathrm{H}_{2} \mathrm{O}$ \\
\hline & concentration & - \\
\hline & Temperature $\mathrm{T}$ & $70^{\circ} \mathrm{C}$ \\
\hline & bath time $t_{k}$ & 1 second \\
\hline & draining time $t_{o}$ & 1 minute \\
\hline & $\begin{array}{c}\text { manipulator } \\
\text { moving } \\
\text { time } \mathrm{t}_{\mathrm{m}} \\
\end{array}$ & 1 minute \\
\hline \multirow{2}{*}{$\begin{array}{l}\text { Complementary } \\
\text { washing }\end{array}$} & washing method & immersion \\
\hline & washing liquid & $\begin{array}{l}\text { Ardox } \\
\text { A/188 }\end{array}$ \\
\hline
\end{tabular}




\begin{tabular}{|c|c|c|}
\hline & concentration & $15 \%$ \\
\hline & Temperature $\mathrm{T}$ & $92^{\circ} \mathrm{C}$ \\
\hline & bath time $t_{k}$ & 10 minutes \\
\hline & draining time $t_{o}$ & 1 minute \\
\hline & $\begin{array}{l}\text { manipulator } \\
\text { moving } \\
\text { time } t_{\mathrm{m}} \\
\end{array}$ & 1 minute \\
\hline \multirow{7}{*}{$\begin{array}{l}\text { Rinsing after the } \\
\text { complementary } \\
\text { washing }\end{array}$} & washing method & immersion \\
\hline & washing liquid & $\mathrm{H}_{2} \mathrm{O}$ \\
\hline & concentration & - \\
\hline & Ambient & $\begin{array}{c}\text { temperature } \\
\mathrm{T}\end{array}$ \\
\hline & bath time $t_{k}$ & 1 second \\
\hline & draining time $t_{o}$ & 1 minute \\
\hline & $\begin{array}{l}\text { manipulator } \\
\text { moving } \\
\text { time } t_{\mathrm{m}}\end{array}$ & 1 minute \\
\hline \multirow{7}{*}{$\begin{array}{l}\text { Deoxidizing } \\
\text { washing }\end{array}$} & washing method & immersion \\
\hline & washing liquid & $\begin{array}{l}\text { Ardox } \\
\text { A/1873 } \\
\end{array}$ \\
\hline & concentration & $25 \%$ \\
\hline & Temperature $\mathrm{T}$ & $85^{\circ} \mathrm{C}$ \\
\hline & bath time $t_{k}$ & 20 minutes \\
\hline & draining time $t_{o}$ & 1 minute \\
\hline & $\begin{array}{l}\text { manipulator } \\
\text { moving } \\
\text { time } t_{\mathrm{m}}\end{array}$ & 1 minute \\
\hline \multirow{7}{*}{$\begin{array}{l}\text { Rinsing after the } \\
\text { deoxidizing } \\
\text { washing }\end{array}$} & washing method & immersion \\
\hline & washing liquid & $\mathrm{H}_{2} \mathrm{O}$ \\
\hline & concentration & - \\
\hline & Ambient & $\begin{array}{c}\text { temperature } \\
\mathrm{T} \\
\end{array}$ \\
\hline & bath time $t_{k}$ & 1 second \\
\hline & draining time $t_{o}$ & 1 minute \\
\hline & $\begin{array}{l}\text { manipulator } \\
\text { moving } \\
\text { time } t_{\mathrm{m}}\end{array}$ & 1 minute \\
\hline \multirow{7}{*}{ Final rinsing } & washing method & immersion \\
\hline & washing liquid & $\begin{array}{c}\text { demineralised } \\
\text { water }\end{array}$ \\
\hline & concentration & - \\
\hline & Ambient & $\begin{array}{c}\text { temperature } \\
\mathrm{T}\end{array}$ \\
\hline & bath time $t_{k}$ & 1 second \\
\hline & draining time $t_{o}$ & 1 minute \\
\hline & $\begin{array}{c}\text { manipulator } \\
\text { moving } \\
\text { time } \mathrm{t}_{\mathrm{m}}\end{array}$ & 1 minute \\
\hline \multirow{7}{*}{ Drying } & drying method & $\begin{array}{l}\text { chamber } \\
\text { drying }\end{array}$ \\
\hline & washing agent & air \\
\hline & concentration & - \\
\hline & Temperature $\mathrm{T}$ & $85^{\circ} \mathrm{C}$ \\
\hline & drying time $t_{\mathrm{s}}$ & 4 minutes \\
\hline & draining time $t_{o}$ & - \\
\hline & $\begin{array}{c}\text { manipulator } \\
\text { moving } \\
\text { time } \mathrm{t}_{\mathrm{m}}\end{array}$ & 1 minute \\
\hline $\begin{array}{c}\text { Grease residues } \\
\text { level control }\end{array}$ & \multicolumn{2}{|c|}{$\begin{array}{l}\text { Apply the test liquid }\left(45 \mathrm{~mJ} / \mathrm{m}^{2}\right) \\
\text { on the surface. Check if the test } \\
\text { liquid coat is even. }\end{array}$} \\
\hline $\begin{array}{l}\text { Solid matter } \\
\text { residues level } \\
\text { control }\end{array}$ & \multicolumn{2}{|c|}{$\begin{array}{l}\text { 1. Select a random washed } \\
\text { element. } \\
\text { 2. Rinse the element thoroughly } \\
\text { with pure solvent. } \\
\text { 3. Filter the solvent with the use } \\
\text { of a test membrane. }\end{array}$} \\
\hline
\end{tabular}

\begin{tabular}{|l|l|}
\hline & $\begin{array}{l}\text { 4. Measure the membrane } \\
\text { weight - the acceptable limit of } \\
\text { the impurities' weight equals } \\
100 \mathrm{mg} \text { per 1 kg of the } \\
\text { controlled element } \\
\text { If the acceptable limit of the } \\
\text { impurities' weight is exceed, the } \\
\text { conditional operation with the } \\
\text { same process parameters should } \\
\text { be undertaken. } \\
5 . \text { Measure the amount and the } \\
\text { size of the impurities - the } \\
\text { acceptable amount of impurities } \\
\text { equals } 25 \text { per 1 kg } \\
\text { of the controlled element, } \\
\text { provided that the biggest } \\
\text { element is less than 0,015 mm. } \\
\text { If the acceptable limit of the } \\
\text { amount and the size of the } \\
\text { impurities is exceeded, } \\
\text { the conditional operation with } \\
\text { the same process parameters } \\
\text { should be undertaken. }\end{array}$
\end{tabular}

Figures 4 and 5 show the condition of the intake duct housing's internal surface before and after the washing process with the use of the automatic washing process line.

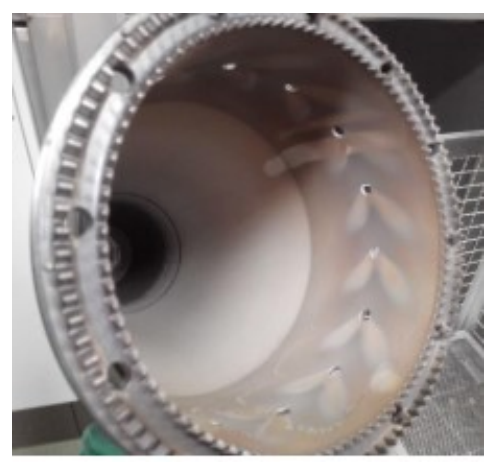

Fig. 4. The condition of the intake duct housing's internal surface before the washing process with the use of the automatic washing process line.

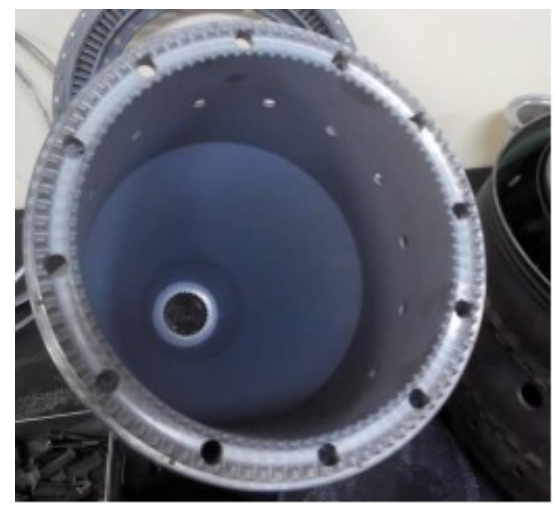

Fig. 5. The condition of the intake duct housing's internal surface after the washing process with the use of the automatic washing process line.

Based on the aforementioned figures, it may be stated that the elaborated technological process shows high effectiveness. However, it was only assessed visually. 
A more accurate result of the process is possible to acquire only after verification with the use of test membranes.

\section{Summary and Conclusions}

The following conclusions were drawn based on the presented analysis:

- various types of contaminants that deposit on the surface of elements during production and treatment process affect their quality, functionality and life;

- the components' surface cleaning methods during the renovation process play a vital role in restoring their usability and enabling for further technological process' stages;

- the already elaborated and used surface cleaning methods let their optimal use in specific cases, taking into consideration the assumed criteria in terms of reasonable costs and quality;

- the necessity of gaining the best effects possible has led to the improvement of traditional methods, as well as to the development of the new ones, which require the use of modern and advanced technologies;

- automation of the washing process has ensured the process' repeatability, high quality and environment protection requirements, as well as safety and hygiene at work;

- the degree of purity of the cleaned elements may be assessed both visually and with the use of various tools. The choice of a proper cleanliness degree assessment method depends on the type of element, designation and the cleaning method that was used;

- it is of high importance to optimise the technological process of washing when elaborating it, as it ensures obtaining the most efficient parameters, the highest quality and the lowest costs of the machine's work possible;

- the type of the washing process line, as well as washing methods, detergents and the order of subsequent stages are determined by the type of the washed elements, material they are made of and the degree of contamination.

The elaborated process of washing with the use of the automated process line improves the aircraft engine renovation process. The possibility of changing the parameters makes it easily adjustable to the constant technological development connected with using more and more modern construction materials and economical and environmental requirements.

\section{References}

1. R.D. Adams, Adhesive bonding. Science, technology and applications (Woodhead Publishing Limited, UK, 2010)

2. E.G. Babraj, D. Starikov, J. Evans, G.A. Shafeev, A. Bensaoula, Int J Adhes Adhes. 27, 268-276 (2007)

3. G.W. Critchlow, D.M., Int J Adhes Adhes. 16, 255-275 (1996)
4. G.W. Critchlow, K.A. Yendall, D. Bahrani, A. Quinn, F. Andrews, Int J Adhes Adhes. 26, 419453 (2006)

5. S. Legutko, Podstawy eksploatacji maszyn I urządzeń [Basics of Machines' and Devices' Exploitation], (Wydawnictwa Szkolne i Pedagogiczne, Warsaw, 2004)

6. W. Polini, L. Sorrentino, Int J Adhes Adhes. 27, 1-8 (2007)

7. G. Rozovskis, J. Vinkevičius, J Adhes Sci Technol. 10, 399-406 (1996)

8. Rudawska, Jo J Adhes Sci Technol. 26, 1233 1247 (2012)

9. J. Andziak, Mechanik. 25-27 (1975)

10. T. Burakowski, Marczak J., Napadłek W., PIEl, Notebook no 228, 126-132 (2006)

11. N. Brack, A.N. Rider, Int J Adhes Adhes. 44, 20 27 (2014)

12. L. Domingues, J. C. S. Fernandes, M. Da Cunha Belo, M. G. S. Ferreira, L. Guerra-Rosa, Corros Sci. 45, 149-160 (2003)

13. Jędrusik, J. Łunarski, TiAM. 1, 52-55 (2013)

14. B.B. Johnsen, F. Lapique, A. Bjørgum, Int J Adhes Adhes. 24, 153-161 (2004)

15. O. Lunder, F. Lapique, B. Johnsen, K. Nisancioglu, Int J Adhes Adhes. 24, 107-117 (2004)

16. S.G. Prolongo, A. Ureña, Int J Adhes Adhes. 29, 23-31 (2009)

17. Rudawska, J. Kuczmaszewski, Mater Sci-Poland. 24, 975-981 (2006)

18. T. Burakowski, T. Wierzchoń, Inżynieria powierzchni metali [Metal Surface Engineering], (WNT, Warsaw, 1995)

19. Koss, J. Marczak, Czas. Tech. 199-204 (2009)

20. W. Brockmann, P.L. Geiß, J. Klingen, B. Schröder, Adhesive bonding. Materials, Applications and Technology (Weinheim, Germany, Wiley-Vch Press, 2009)

21. R.E. Litchfield, G.W. Critchlow, S. Wilson, Int J Adhes Adhes. 26, 295-303 (2006)

22. Rudawska, Int J Adhes Adhes. 50, 235-243 (2014)

23. J.M. Sykes, Surface treatment for steel, in: Brewis DM. (Eds.), Surface Analysis and Pretreatment of Plastics and Metals (Applied Science Publishers, London, 1982)

24. P.R. Underhill, A.N. Rider, D.L. DuQuesnay, Int J Adhes Adhes. 26, 199-205 (2006)

25. J. Konieczny, Armia. 4 56, 70 (2013)

26. https://www.hotwash.com.au/wpcontent/uploads/2014/07/15-Product-Profile 